ORCID: 0000-0001-8255-7803

University of Silesia, Poland 1

\title{
Employees' poverty: Poland in comparison to other EU countries
}

\begin{abstract}
The article attempts to show the problem of the differentiation of the risk of poverty among people working in the European labour market. Based on Eurostat research (the EU-SILC survey), the text presents the dynamics of changes in the phenomenon of in-work poverty in individual EU countries in 2006-2019. A particularly significant increase in this unfavourable phenomenon in 2006-2019 was observed in Bulgaria, Germany, Hungary, Malta and the Netherlands. A clear decrease of the share of people at risk of poverty among the employed was recorded in Finland, Serbia, Poland, Latvia and Ireland. The analysis of the regression models allows us to predict that in Poland, in the coming years, impoverishment of working people will decrease.

The article presents the factors that have a key impact on the problem of impoverishment of the economically active. The analysis of the empirical material showed that the factors significantly influencing the level of pauperisation of working people are low level of education, flexible work, part-time work, young age, low work experience and living in multiperson households.
\end{abstract}

Key words: labour market, precariat, working poor, European Union, EU-SILC survey

1 Correspondence: Instytut Socjologii, Uniwersytet Śląski w Katowicach, ul. Bankowa 11, 40-007 Katowice, Polska; author's email address: rafal.muster@us.edu.pl 
Introduction

The phenomenon of pauperisation of the employed has been widely described in the Anglo-Saxon literature, particularly in the United States (compare Swartz \& Weigert, 1996; Newman, 1999; 2006; Shipler, 2005; Ehrenreich, 2006; Newman \& Tan Chen, 2007 and others). Above all, the United States is the only country possessing a legal definition of working poor (compare Muster, 2012, p. 35). It is in the USA that this phenomenon very frequently constitutes the subject of scientific exploration simultaneously being present in the media discourse. However, as stated in the literature on the subject: "the term working poor was first used by French sociologists in the 1980s in reference to temporary and season workers" (Goleński, 2015, p. 17). This signifies that originally this term was strongly connected with the stability of employment and it referred to those employed in flexible form. Nowadays, the range of the notion of the term working poor mostly places emphasis on the issues of financial remuneration received for providing work which naturally also derives from the stability of employment of an individual.

In recent years - according to researchers - both in the United States of America and in Europe a lot of attention has been given to the issue of low-paid employees who experience poverty in spite of obtaining regular income, not only in political debates and media discourse but also in scientific literature (Stanaszek, 2004, p. 143; Zabielska, 2007, p. 25; Cymbranowicz, 2017, p. 170).

The phenomenon of poverty threat among professionally active individuals resulting from their low incomes is also noticeable in Poland (compare: Hardy, 2010, p. 185; Szczepański et al., 2006, p. 22). In recent years, this social issue constituted the subject of scientific articles (compare for instance Stanaszek, 2004; Kozek et al., 2005; Frysztacki, 2009; Muster, 2012; Wójcik-Żołądek, 2013; Goleński, 2015; Kalinowski, 2015; Polkowska, 2016; Góra, 2016; Kryńska, 2017; and others). The problem of working poor has been noticeable also in the domestic media discourse for at least a decade (compare Suchodolska, 2015; Nowakowska, 2018). It is also worth point out the series of studies by the Polish Panel Society (POLPAN), and in particular other studies by Anna Kiersztyn, who analyses the issues of income marginalization (see, for example, Kiersztyn, 2007a, 2018, 2020). The problem of poverty — including working people - was also studied by K. Frieske (2008), S. Golinowska (2018), J. Grotowska-Leder (2018), A. Mrozowicki (2020), A. Krasowska (2020), and J. Czarzasty (2020). However — a fact that needs stressing — we are definitely lacking comprehensive studies and analyses of this phenomenon at the domestic level of both quantitative and qualitative nature 2 .

In literature on the subject, it has been frequently emphasised that: "work and poverty occurring together constitute a situation also contradicting common sense" (Szamrej-

2 Among the limited number of representative studies which referred to the issue of poverty among employed Poles we may list the analyses of 2007 conducted by the Centre for Public Opinion Research CBOS (Kuźmicz \& Stasiowski, 2008). In the same year a research project entitled "Working Poles" entailing among others an attempt at diagnosing the scale of poverty in the environment of working Poles was conducted at Warsaw School of Economics - see: J. Gardawski, 2009, p. 37. 
-Baran, 2014, p. 292). Krzysztof Frysztacki described such situation - the coexistence of poverty and employment - as a logical contradiction (Frysztacki, 2009, p. 93). Undoubtedly, low remuneration is deeply frustrating for individuals performing work which does not guarantee their social security. In such cases, employment loses its basic sense as professionally active individuals are not capable of providing themselves and their families with decent standard of living (compare Muster, 2011, p. 65).

In fact, an in-depth analysis of this phenomenon, operating on gathered data instead of solely on the already existing materials based on the analysis of statistical sources would definitely allow researchers to answer a series of questions regarding poverty occurring in spite of being employed. Undoubtedly, researchers should focus on the fact that certain part of the professionally active prefers providing work to being professionally passive and benefiting from possible social transfers aimed at the unemployed. As observed by E. Polak, the working poor "cannot benefit from privileges designed for the unemployed while simultaneously their incomes are insufficient to guarantee a decent standard of living" (Polak, 2011, p. 101). Moreover, the remuneration they obtain is frequently at a similar level as benefits they would be entitled to as unemployed individuals.

The percentage of professionally active individuals threatened by poverty within the population changes in time and occurs in every analysed European labour market. In the period of economic crisis and also for some time afterwards, we have been observing intensification of this phenomenon (compare Domański, 2007, p. 84). Besides, economic crisis does not only imply a reduction of employment, but it also translates into the decline of the sense of employment stability among those individuals who have not been directly affected by the said reductions. Jeremy Rifkin has proposed a thesis that the global increase of the unemployment rate - always occurring in the period of economic crisis - also results in a qualitative change of the accessibility of workplaces. In his opinion, the number of workplaces not requiring high technical or social competences will grow. Such positions are usually low-paid and in large proportion based on flexible forms of employment (Rifkin, 2003). Thus, the percentage of job offers from the so-called secondary labour market is growing considerably. In opposition to the primary labour market, this section of the labour market offers positions which are badly paid, unstable, require greater effort or intensity and provide minimal opportunities for promotion (Kozek, 2014, p. 116). A new social class is being created: one consisting of individuals whose incomes are close to the poverty threshold. Consequently, in the period of economic crisis as well as during several years following such period, an increase in pauperisation among a certain part of the employed is to be expected - a fact clearly noticeable in the area of the European labour market after the year 2008. We may expect that another economic crisis predicted by analysts (compare e.g., Zelek, 2018) in next several years will adversely influence the income level of part of professionally active individuals. Although analysts have predicted the subsequent economic crisis, their models have not envisioned that such crisis will be caused by a worldwide epidemic.

The purpose of this article is depicting, on one hand, the diversification of poverty threat among the employed in the area of the European labour market, and on the other - an attempt at diagnosing the factors determining this threat. When aiming at describing 
the problem of pauperisation of certain part of the employed in the contemporary labour market, the researchers resorted to the data collected on the basis of the EU-SILC survey. Thanks to the analysis of the results of the conducted analyses in various periods of time, an attempt was made to represent the variable dynamics of this phenomenon in relation to time. Comparisons of statistical data from various countries enhanced the diversification of scale of occurrence of this phenomenon in different European states.

\section{On the terms precariat and working poor}

Stereotypically, poverty is associated with lack of employment, with long-term unemployment, with factors estranging an individual from the area of the labour market. However, as shown by empiric studies, the problem of poverty also touches professionally active individuals. We may even talk about a category of employed individuals threatened by poverty - as statistical data demonstrates, this problem affects nearly every tenth employed individual in the European Union.

The topic of precarians and precarious labour in the state of the art was popularised by British economist Guy Standing (Standing, 2014, 2015). At times, however, the problem of pauperisation of the employed is identified and treated equally with the issue of precarisation. Still the meaning of the term precarity is wider and definitely extends beyond the definition of material pauperisation, a fact that was clearly stressed by Standing in his works $(2014,2015)$. Marek Góra strongly emphasised that precarians are not necessarily threatened solely and exclusively by poverty. The point here is more the issue of insecurity - concerning their professional perspectives, their private plans connected with starting a family or extreme danger of being trapped in a spiral of debts difficult to pay back (Góra, 2016, p. 268).

According to Standing's, concept, we may differentiate seven types of security connected with employment, out of which only one (the sixth one) in fact relates directly to the aspect of material gratification for the performed work (Standing, 2014, p. 49):

1. Security in the labour market - policy of full employment realised by the legislator at the macrolevel.

2. Employment security - protection against arbitrary dismissal of employees, appropriate legal regulations concerning employing and dismissing employees.

3. Workplace security - opportunity for social promotion in terms of status and income.

4. Work security - protection against accidents at the workplace through applying proper OHS regulations; reducing work in adverse conditions.

5. Security of skills reproduction - the opportunity to obtain appropriate skills through on-the-job training, other trainings, chances to implement possessed competences at work.

6. Income security - guarantee of adequate income protected by the mechanism of minimum wage adjusted to the inflation level.

7. Representation security - employees' participation, ability to join trade unions, securing the right to go on strike. 
At the same time, we need to emphasise that the Dictionary of the Polish Language still does not include the definition of the term precariat. This term stems from the English word precarity or the French precarité (both meaning "unstable situation"). In the Dictionary of the English Language, we may encounter a twofold understanding of the term precarious. The first one is compliant with the iteral sense: "Something that is precarious is in a dangerous state or position because it is not securely held in place and seems likely to fall down or collapse at any moment". And the second: "If your situation or position is precarious, you are not secure because you are not in complete control of events and might fail in what you are doing" (compare: Collins Cobuild English Language Dictionary, 1990, p. 1126). These statements may be related both to an object that might fall at any moment and to people, in which case this term signifies a lack of sense of security, insecurity, lack of control over the course of specific events.

Jan Sowa emphasises that the term precariat is etymologically related to the Latin root caritas (compassion, love of fellow human beings, care) and describes the conditions of an object (or a person) one should care for or who - due to their tragic situation - require prayer and are at the mercy of others. Thus, we may conclude that the etymology of the term precariat stems from the Christian ideology and refers to someone or something that requires prayer due to their dramatic position or is totally dependent of the mercy of others (on-line: http://ha.art.pl). Thus, the lack of stability is closely connected to the term "precariat" and the position of an individual in the space of the labour market determines the subjective perception of stability or of lack thereof to a large extent. As observed by Karolina and Łukasz Rąb: "individuals affected by precarity experience numerous serious problems such as: insecurity, lack of career perspectives and also - general discontentment" (Rąb \& Rąb, 2015, p. 171). As mentioned before, the only country possessing a legal definition of the working poor is the United States, where this category includes the individuals who spend 27 weeks or more in a year in the labor force either working or looking for work but whose incomes fall below the poverty level. On the other hand, Eurostat defines the term of "working poor" as "low income threshold: less than $60 \%$ of the median equivalized household income" (Pena-Casas \& Latta, 2004, p. 7). For the purpose of this paper, this category shall include individuals with low income that is below $60 \%$ of the median of equivalized household income per capita.

\section{Working poor in selected empiric studies}

The problem of working poor - as it has been emphasised before — is particularly widely described and commented also in the scientific literature in the United States. At this point, it is justifiable to refer to the category of the missing class. This term, which signifies an invisible or absent class, first appeared in the book by Katherine S. Newman and Victor Tan Chen (2007). This work describes the fates of average individuals who work performing badly paid jobs (cleaners, waiters, shop assistants). Such individuals frequently work in several companies and due to the considerable amount of time devoted to work, they neglect their families. These people are not poor but usually, due to their 
lower material status, they reside in worse districts where places and individuals who break the law are gathered. We may suspect that work holds a relatively high position in the system of values of the professionally active representatives of the missing class - they prefer to work rather than benefit from social services. However, their low qualifications and the nature of performed jobs do not provide them with opportunities for professional development and consequently, despite performing intense work (frequently for few employers), individuals belonging to the category of the missing class additionally do not possess the possibility to accumulate capital (Newman \& Tan Chen, 2007, pp. 1-6).

In other texts (1999; 2006), Newman describes the problems of the employed residents of the New York district of Harlem who live in poverty. A large percentage of these individuals are of Afro-American and Latino origin and due to lack of better-paid positions, they decide to perform short-term, seasonal jobs. The obtained renumeration is sufficient, although not always, to satisfy their elementary needs. Analogically, in her book "Nickel and Dimed" (2006), Barbara Ehrenreich assumes the role of badly paid workers (a waitress in a fast-food bar, a shop assistant in a supermarket, a cleaner) completely changing her current lifestyle. The author describes mechanisms hindering escaping poverty which constitute the daily experience of the working poor in the USA, earning 6-7 dollars per hour. Their professional activity does not allow them to improve their material or social status. The performed jobs are exhausting both intellectually and physically and in order to be able to pay their bills, one needs to work in at least two places. Thus, such individuals neglect other spheres of life, including their health, and they do not devote enough time to their children.

Similarly, in the conducted analyses regarding the problem of working poor, E. Crettaz concludes that this category is preliminarily created by individuals possessing low qualifications, employed by smaller companies where trade unions rarely exist. The issue of pauperisation is also related to the problems of providing work within flexible forms of employment or performing work as a subcontractor who is obliged to start their own company. These individuals struggle with the issue of lack of stability in the labour market. And it is among such persons that we encounter professionally active single mothers (compare Crettaz, 2013).

The analysis by the U.S. Bureau of Labor Statistics clearly hints at the corelation between the percentage of working poor in the population of the employed depending on the periodicity of changes occurring within economy. It appears that the percentage of the working poor increases in times of economic crisis. For instance, in the period between 2007 and 2008, the percentage of working poor reached the level of 5.1\%, but in the period between 2009 and 2013, this percentage increased reaching the level of 7\% (https://www.bls.gov/opub/reports/working-poor/2018/home.htm). In course of analysis of the data originating from the United States for the year 2018, we may observe that taking gender into consideration, this type of poverty affects women more frequently $(5.3 \%)$ than men $(3.7 \%)$. If we consider the racial aspect, we can clearly observe that the indicators of poverty among the employed grow for individuals of Afro-American (7.8\%), Hispanic or Latino (7.9\%) origin. Another well visible dependency may be noted when we analyse the 
education level of the working poor. The percentage of working poor among individuals with university education equalled $1.4 \%$. However, among employees with education level lower than secondary this indicator reaches the level of $13.5 \%$. Another important factor related to the issue of pauperisation of professionally active individuals is connected with their working hours. The issue of poverty of the employed affects solely $2.6 \%$ of those who are employed full-time (https:/www.bls.gov/opub/reports/working-poor/2018/home.htm).

Single representative studies conducted in the Polish local labour market (CBOS, 2008) suggest that the category of working poor includes younger individuals $(55.1 \%$ of the working poor were younger than 40), residing in the countryside and smaller towns with maximum population of 20 thousand inhabitants $(70.2 \%)$ possessing low formal education - no higher than secondary vocational education $(63.1 \%)$. The research by CBOS (Centre for Public Opinion Research) has also proven that working poor are most frequently employed by private companies.

The domestic literature on the subject more and more frequently contains analyses regarding the representatives of individual professions threatened by pauperisation due to low material remuneration. What is more, the term "officeriate" has even appeared as a description of those employed at clerical positions (compare Szaban, 2013). This term refers to the representatives of the administration and office personnel who earn a low salary for the performed work. Publications concerning representatives of various professional groups at risk of material poverty have appeared in the domestic market. For instance, it is worth mentioning the articles discussing the problem of low salaries of, among others, nurses (Kubisa, 2014) or teachers (Stepaniuk, 2018).

On the other hand, Anna Kiersztyn points out that people with low work experience function in the secondary labour market as, inter alia, unskilled workers, blue-collar workers, retail workers and personal services workers (2014). Work in these professions is clearly related not only to low wages (Kiersztyn, 2007b), but also to the lack of stabilization in the labor market (Kiersztyn, 2020). However, due to the possibility of comparing empirical data from various countries the article describes the phenomenon of working poor using the methodology of EU-SILC survey which allows for comparison of data from different states.

\section{The methodology frames of the EU-SILC survey}

The European Union Statistics on Income and Living Conditions survey abbreviated to EU-SILC has been conducted since 2003. At present, 28 states of the European Union as well as Island, Norway and Switzerland participate in the study (Arora et al., 2015, p. 453). This study, which is realised annually, is used mainly for subsequent economic and demographic analyses (Greulich \& Dasré, 2017, p. 526). The EU-SILC survey is conducted on representative samples of the total population of approximately 500000 inhabitants of Europe. The credibility of this study, its comprehensive character and common methodology frames allow for the comparison of results between individual countries (compare Arora et al., 2015, p. 451). The methods of obtaining research material 
are truly diversified and they include CATI, CAPI, PAPI (compare Arora et al., 2015, p. 453). The EU-SILC survey constitutes the point of reference for comparison of statistics regarding the distribution of incomes and social integration within the European Union. It is applied in order to monitor social policy through the Method of Open Coordination (on-line: www.ec.europa.eu/eurostat). As stated by GUS (Polish Central Statistical Office): "The main objective of the European Union Statistics on Income and Living Conditions survey (EU-SILC) is to gather comparable data concerning living conditions for the states of the European Union. The EU-SILC survey constitutes the basic source of information used for calculating, among others, indicators of income, poverty and social exclusion for the EU member states. The set of statistical indicators regarding this area approved by Laeken European Council in December 2001 is designed to enhance monitoring of progress in reaching objectives in the scope of fighting poverty and social exclusion agreed upon by the EU member states" (GUS, 2014, p. 17). In Poland, the said survey is conducted by the Central Statistical Office.

The organisation and methodology of the EU-SILC survey is determined by legal frames and stems from the stipulations of the ordinance of the European Parliament no. 1177/2003 of the 16th of June 2003 (with modifications introduced by the ordinance no. 1553/2005) concerning the statistics of incomes and conditions of living and also by corresponding regulation of the European Commission (GUS, 2014, p. 18).

This article attempts at depicting - on the basis of the available statistical data - not only the most current state of the risk of poverty among the professionally active individuals, but also at presenting trends of the occurring changes.

The risk of poverty is "the share of people with an equivalised disposable income (after social transfer) below the at-risk-of-poverty threshold, which is set at $60 \%$ of the national median equivalised disposable income after social transfers. This indicator does not measure wealth or poverty, but low income in comparison to other residents in that country, which does not necessarily imply a low standard of living (https://ec.europa.eu/ eurostat/statistics-explained/index.php?title=Glossary:At-risk-of-poverty_rate). On the other hand, pauperisation is a process lasting over time that concerns the decline in the standard of living of people and the community. However, as it has been strongly emphasised in the state of the art, the said data is published with a delay (compare: Siergiejuk, 2018, p. 6). Hence, depending on the accessibility of certain parts of presented data they refer to the year 2019, while other data concern the year 2018.

\section{The threat of poverty among the employed in the states of the European Union}

In course of analysis of the phenomenon of the working poor in the period of the recent thirteen years (2006-2019) on the basis of Eurostat data, we may observe an increase of the percentage of individuals threatened by poverty among the employed in the majority of the analysed European states. In spite of the fact that income discrepancies 
measured on the basis of the Gini coefficient ${ }^{3}$ for the analysed states are at medium or moderate level (compare Therborn, 2015, pp. 130-131; Raczkowska, 2015a, p. 354), not only may we talk about the appearance of the working poor in the European territory, of Europe but also about this phenomenon intensifying in recent years.

What is more, in the analysed period of time, a particularly high increase in the amount of working poor occurred after the last economic crisis in 2008. Thus, not only did the economic recession lead to the increase in the unemployment indicators, but also to the reduction of actual income of professionally active individuals. However - a fact strongly emphasised by S. Kalinowski and W. Luczka - the material situation of a working poor in various countries is different (2015, p. 113). Thus, we may talk about the issue of relativisation of poverty. A person considered poor in Luxembourg in another country may be classified as a relatively well-off citizen. As shown by Eurostat research, the greatest percentage of individuals threatened by poverty among the employed was observed in 2019 in the following states: Romania (15.4\%), Spain (12.8\%), Luxembourg $(12.0 \%)$ and Italy (11.8\%). On the other hand, the smallest percentage of the employed threatened by poverty was registered in the following six European states: Finland (2.9\%), the Czech Republic (3.5\%), Belgium (4.8\%), Ireland (4.4\%), Slovakia (4.4\%) and Slovenia $(4.5 \%)$. In Poland, the scale of this phenomenon in the population of the employed aged between 18 and 64 reached $9.9 \%$ in 2019. A particularly considerable growth of this unfavourable phenomenon in the period between 2006 and 2019 was observed in Bulgaria, Germany, Denmark, Malta, Hungary and Netherlands. A visible reduction of the scale of participation of those at risk of poverty among the population of the employed was recorded in Finland, Serbia, Ireland and Slovakia (Table 1).

3 The Gini coefficient presents the average absolute difference between incomes of two randomly selected entities (e.g., households) in relation to the average income. The values of the coefficient fall within the range of [0-1] - the lower value of the coefficient the more even income distribution. If the value of this coefficient does not exceed 0.3 it signifies that the given state is characterised by relatively small income diversification, value between $0.3-0.45$ indicates medium income diversification. However, the coefficient value above 0.45 is typical for states with high or even very high level of income diversification. If the coefficient reached the hypothetical value " 0 " it would signify that the incomes of individual members of the analysed population are identical and if the coefficient equalled " 1 " that would signify that all individuals apart from one person obtain zero income. Sometimes, this coefficient is multiplied by 100 (see: Raczkowska, 2015b; Domański, 2012; www.stat.gov.pl/metainformacje/slownik-pojec/pojecia-stosowane-w-statystycepublicznej/3078,pojecie.html). 
Table 1. Percentage of individuals threatened by poverty among employed individuals (aged 18-64) in selected European countries (comparison of three years: 2006, 2014 and 2019, in \%)

\begin{tabular}{|c|c|c|c|c|}
\hline Countries & 2006 & 2014 & 2019 & $\begin{array}{c}\text { Change between } 2006 \\
\text { and } 2019 \text { in \% }\end{array}$ \\
\hline Austria & 6.3 & 7.2 & 7.7 & +22.2 \\
\hline Belgium & 4.0 & 4.8 & 4.8 & +20.0 \\
\hline Bulgaria & 5.5 & 9.3 & 9.0 & +63.6 \\
\hline Cyprus & 7.2 & 7.8 & 6.8 & -5.5 \\
\hline Croatia & not available & 5.7 & 5.0 & -12.3 \\
\hline Czech Republic & 3.5 & 3.6 & 3.5 & 0.0 \\
\hline Denmark & 4.5 & 4.8 & 6.3 & +40.0 \\
\hline Estonia & 7.8 & 11.8 & 10.3 & +32.1 \\
\hline Finland & 4.4 & 3.7 & 2.9 & -34.1 \\
\hline France & 6.0 & 8.0 & 7.4 & +23.3 \\
\hline Greece & 13.7 & 13.2 & 10.1 & -26.3 \\
\hline Spain & 10.1 & 12.6 & 12.8 & +26.7 \\
\hline Netherlands & 4.4 & 5.3 & 5.4 & +22.7 \\
\hline Ireland & 6.2 & 5.5 & 4.4 & -29.0 \\
\hline Lithuania & 10.1 & 8.4 & 8.1 & -19.8 \\
\hline Luxemburg & 10.3 & 11.1 & 12.0 & +16.5 \\
\hline Latvia & 11.2 & 8.3 & 8.7 & -22.2 \\
\hline Macedonia & not available & 9.7 & 8.4 & -13.4 \\
\hline Malta & 4.1 & 5.7 & 6.5 & +58.3 \\
\hline Germany & 5.5 & 9.9 & 7.9 & +43.6 \\
\hline Poland & 12.8 & 10.7 & 9.9 & -22.7 \\
\hline Portugal & 10.4 & 10.7 & 10.7 & +2.9 \\
\hline Romania & not available & 19.5 & 15.4 & -21.0 \\
\hline Serbia & not available & 14.9 & 9.1 & -38.9 \\
\hline Slovakia & 6.3 & 5.7 & 4.4 & -30.2 \\
\hline Slovenia & 4.8 & 6.4 & 4.5 & -6.3 \\
\hline Sweden & 7.4 & 7.8 & 7.7 & +4.0 \\
\hline Hungary & 6.9 & 6.7 & 8.5 & +23.2 \\
\hline United Kingdom & 7.7 & 8.8 & 10.4 & +35.1 \\
\hline Italy & 9.0 & 11.1 & 11.8 & +31.1 \\
\hline UE (19 countries of the Euro zone) & 7.3 & 9.4 & 8.8 & +20.5 \\
\hline UE (28 countries) & 8.0 & 9.6 & 9.2 & +15.0 \\
\hline
\end{tabular}

Important information: in case of the following countries: Croatia, Macedonia, Romania and Serbia, due to the lack of information concerning the percentage of the employed at risk of poverty in 2006 the dynamics of changes was calculated for the period 2014-2019. In case of Great Britain data for the year 2019 is not available hence data for 2018 was used.

Source: Eurostat. In-work at-risk-of-poverty rate by age and sex — EU-SILC survey [ilc_iw01]. 
A fact worth emphasizing: in the period between 2006 and 2014, greater dynamics of growth of the amount of the employed at risk of poverty was recorded in the territory of the EU states belonging to the Euro zone (increase from $7.3 \%$ to $8.8 \%$ ) than in the whole EU (increase from $8.0 \%$ to $9.2 \%$ ). It is also worth adding that in the last few years, a decrease of these indictors was observed in these countries - see Figure 1.

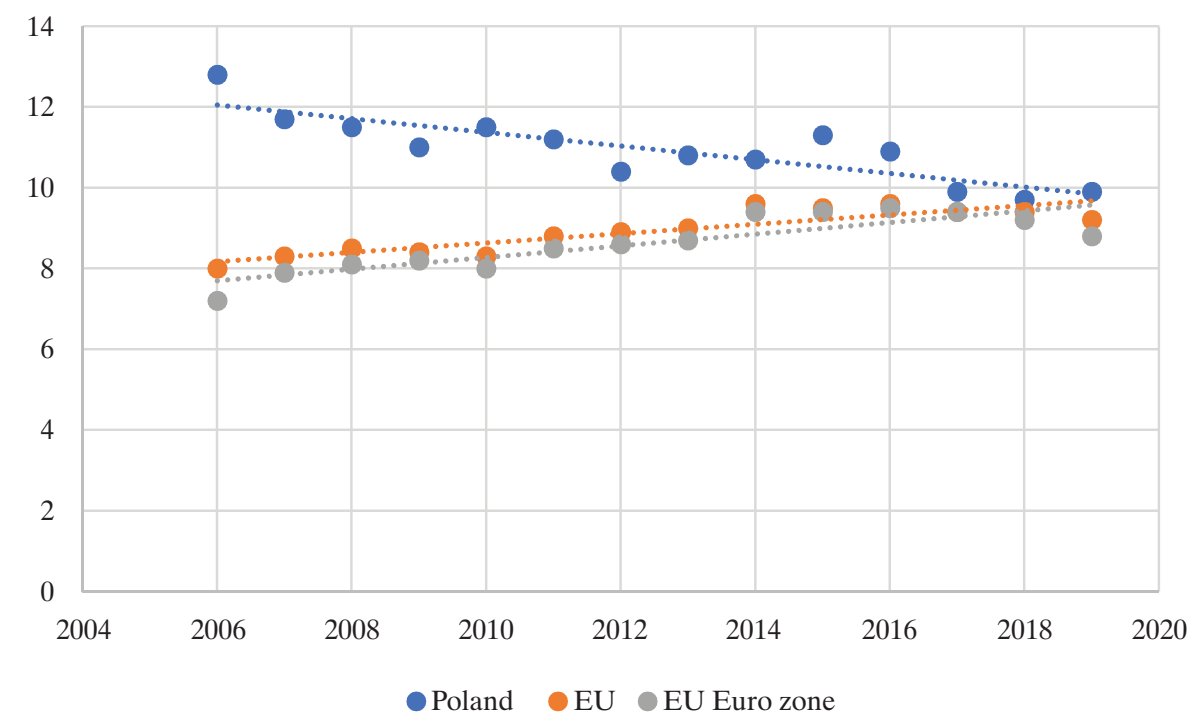

Fig. 1. Linear trend - percentage of the employed (aged 18-64) at risk of poverty - Poland versus other EU states and states of the Euro zone.

Source: Eurostat. In-work at-risk-of-poverty rate by age and sex — EU-SILC survey [ilc_iw01].

Based on the one-way regression analysis, it was found that in Poland, the tendency is decreasing (Beta $=-0.853, \mathrm{p}<0.001$ ), while in the European Union countries, especially in the Euro zone, it is increasing (respectively: Beta $=0.886, \mathrm{p}<0.001$; Beta $=0.864$, $\mathrm{p}<0.001)$. Based on the regression equation and non-standardized coefficients, it is possible to extrapolate the trend to 2030. Based on the obtained data, for Poland, the percentage of working people at risk of poverty is $7.9 \%$, while for the entire EU, it would amount to $11.2 \%$ in 2030, including $10.4 \%$ for the Euro zone. Based on the regression model, it can be predicted that the share of people at risk of poverty in Poland among the employed will decrease in the coming years. This is thanks to, inter alia, social transfers which feed the budgets of households, especially of families with children (the 500+ programme) but is also the result of growing salaries, including the minimum wage. The analysis of the empirical data suggests that the percentage of the employed at risk of poverty in Poland has definitely been reduced and reached values similar to those of the EU states and states of the Euro zone. 


\section{Social and demographic factors influencing the risk of poverty among the employed}

When attempting at diagnosing the factors potentially influencing the issue of poverty among the employed, the following variables and their impact on the problem of pauperisation were taken into consideration: sex, age, education level, employment security, working time schedule, type of household (with or without children) and finally the level of intensity of work. Statistical data concerning Polish labour market have been compared above all with the average European indicators.

The analysis of empirical data (for the end of 2019) shows that in the EU territory, the problem of pauperisation of the employed individuals affects men $(9.6 \%)$ to a greater extent than women (8.8\%). However, in the period between 2006 and 2019, a greater dynamic of growth of this phenomenon was registered among women. In the said period, the percentage of professionally active women at risk of poverty increased from $7.2 \%$ to $8.8 \%$ (growth of $22.2 \%$ ) whereas among men in the same period this value increased from $8.7 \%$ to $9.6 \%$ - that is by $11.6 \%$ (Figure 2).

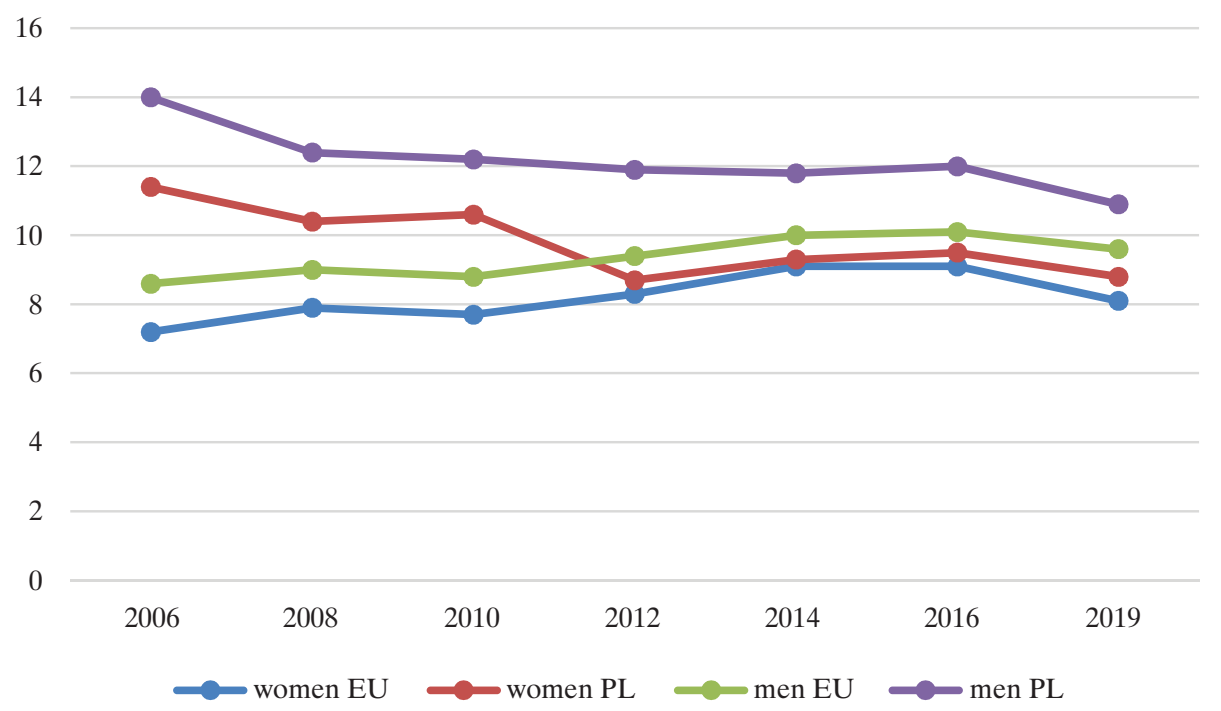

Fig. 2. Percentage of working women and men (aged 18-64) at risk of poverty

- Poland versus other EU states (the period between 2006 and 2019, in \%)

Important: working age for women in Poland ranges from 18 to 60 . However, this age range was not taken into consideration in the accessible statistical date of Eurostat concerning the problem of risk of poverty among the employed. Hence, we refer to the statistical data regarding the age range 18-64 both for Poland and for other EU countries.

Source: Eurostat. In-work at-risk-of-poverty rate by age and sex — EU-SILC survey [ilc_iw01]. 
As shown by statistical data (2019), the percentage of working women threatened by poverty was the highest in Luxembourg (12.0\%) Spain (11.8\%), Romania $(11.2 \%)$, Portugal $(10.5 \%)$ and Italy $(10.1 \%)$. At the other end of the spectrum, the states with the lowest level of occurrence of this phenomenon were: Finland (2.8\%), Slovakia (3.4\%), Slovenia (3.6\%), the Czech Republic (3.7\%), Ireland (4.2\%), Croatia (4.2\%) and Malta $(4.6 \%)$.

The Eurostat research indicates that the coefficient of poverty risk among working women in Poland in 2019 reached the level of 8.8\%. The largest percentage of individuals at risk of poverty among working men in the age group 18-64 in 2019 was registered in the following countries: Romania (18.4\%), Spain (13.5\%), Italy (13.1\%), Luxembourg $(12.1 \%)$, Greece $(11.6 \%)$ and Estonia $(11.3 \%)$. The smallest percentage of working men threatened by poverty was registered in the following states: Finland (3.0\%), the Czech Republic (3.3\%), Ireland (4.5\%), Slovakia (5.2\%), Slovenia (5.3\%), Croatia (5.7\%) and Netherlands $(5.7 \%)$. In Poland, the coefficient of working men at risk of poverty reached the level of $10.9 \%$.

Results of the conducted analyses hint at the following regularity: - the lower the age of the employed, the higher risk of poverty. Yet this dependency is more visible in case of women. According to Eurostat data, the percentage of those at risk of poverty among working women under 24 years of age reaches the level of $11.8 \%$ and then it gradually falls to $8.5 \%$ (for the age group 25-54) and $8.6 \%$ in case of women older than 55. Among men, a similar correlation has been observed - the lower age of the employed, the higher the indicators of pauperisation threat, although differences between individual categories are insignificant. The percentage of the employed at risk of poverty in the youngest age group (18-64) equals $9.8 \%$, subsequently it declines slightly to $9.7 \%$ and $9.4 \%$ respectively among those aged between 25 and 54 and 55 and 64. As noticed by S. Kalinowski and W. Łuczka: "A high percentage of young individuals among the working poor can be easily explained in the context of the fact that young people enter the labour market and need to earn professional experience. Another aspect contributing to the fact that young people fall in the trap of precarity is the popularity of training periods, which, despite providing the opportunity of obtaining professional skills and competences, unfortunately also lead to the decline of the standard of living" (2015, p. 116). What is more, the Eurostat research has revealed an interesting dependency — we are dealing with the risk of poverty affecting men slightly more frequently than women. S. Kalinowski and W. Luczka (2015, p. 115) also have directed their attention to the higher risk of poverty among working men than women. Similarly, in the course of interpreting this phenomenon, E. Kuźmicz has concluded that: "[T]the reason is probably the fact that women are usually the second income earners in the family after men. Thus, even if they obtain a low salary for bad work but they have a working partner whose income is appropriately high, women are not at risk of poverty. In the situation when a man is the only breadwinner for the family, even if his salary reaches the level of national average salary this may place the whole household below the poverty threshold" (Kuźmicz, 2011, p. 46). The detailed data have been presented in Figures 3 and 4. 


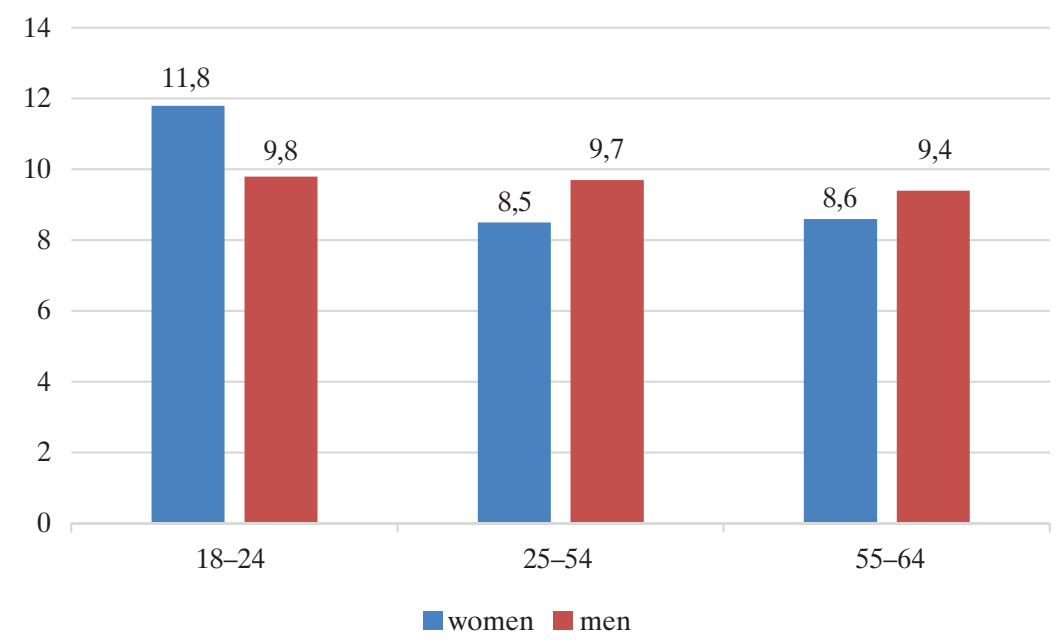

Fig. 3. Percentage of individuals at risk of poverty among women and men (with division into age categories) in the territory of the EU (for the year 2018, in \%)

Source: Eurostat. In-work at-risk-of-poverty rate by age and sex — EU-SILC survey [ilc_iw01].

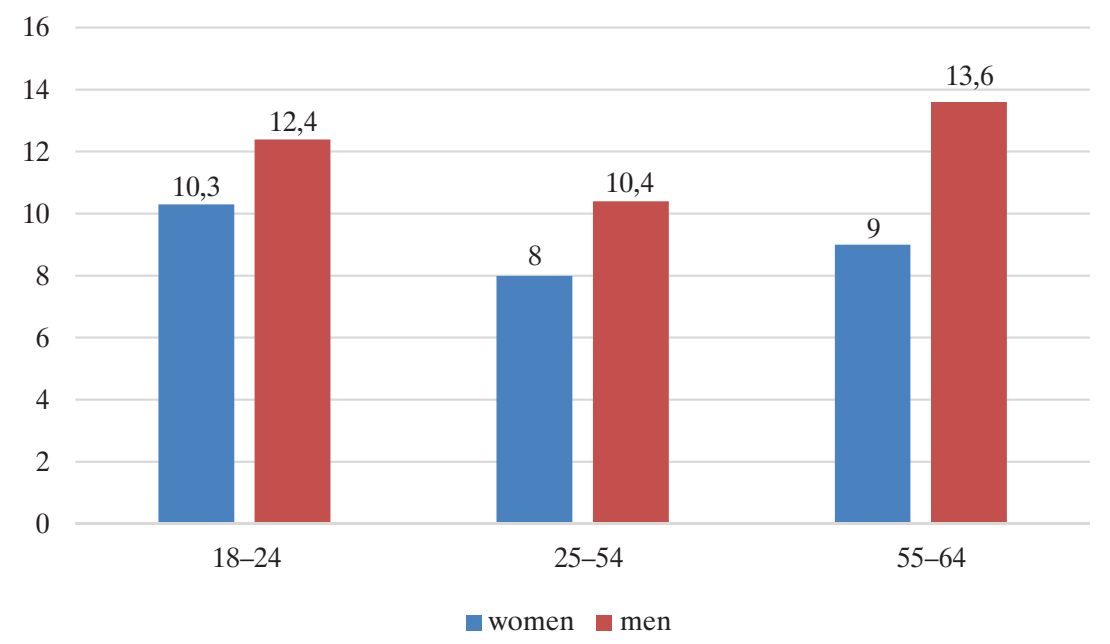

Fig. 4. Percentage of individuals at risk of poverty among women and men (divided into age categories) in Poland (for the year 2018, in \%)

Important: working age for women in Poland ranges from 18 to 60. However, this age range was not taken into consideration in the accessible statistical date of Eurostat concerning the problem of risk of poverty among the employed. Hence, we refer to the statistical data regarding the age range 18-64 both for Poland and for other EU countries.

Source: Eurostat. In-work at-risk-of-poverty rate by age and sex — EU-SILC survey [ilc_iw01]. 
Another important variable determining belonging to the category of working poor to a significant extent is the level of education. Statistical analysis of the gathered empiric material clearly displays a visible dependency - the lower level of education of the professionally active individuals the higher risk of poverty (Table 2). In the territory of the EU the percentage of individuals at risk of poverty with the lowest level of education (incomplete primary, primary and lower secondary education) among the population of the employed in 2018 reached the level of $19.3 \%$ while for individuals with higher secondary education the same indicator was reduced to $9.2 \%$. Additionally, among those with university education the indicator of risk of poverty among the employed reached the value of $4.5 \%$. Similar dependencies were observed in the Polish labour market - the higher level of education, the lower risk of poverty among the employed. Among individuals with incomplete primary, primary or lower secondary education the percentage of those at risk of poverty reached the level of $23.3 \%$ in 2018 , the same value among individuals with post-secondary education was reduced to $12.2 \%$ and among employees with a university diploma it declined even further to $2.9 \%$. Observing the trends of change in the period between 2010 and 2018 in the territory of the EU and taking into consideration the possessed level of education of working individuals threatened by poverty we may notice the increase of this phenomenon in each education group. Surprisingly, although among the employed with university education the indicators of risk of pauperisation are the lowest the dynamics of growth of these indicators is the largest. In Poland, in the period between 2010 and 2018, a reduction in the percentage of the employed at risk of poverty was recorded among employees with incomplete primary, primary and lower secondary education and also among those with post-secondary education, yet an increase of the scale of this phenomenon was observed among employees with university education.

Table 2. Level of education of employees in relation to their risk of poverty in the territory of the EU and in Poland (comparison of the year 2010 and 2018, in \%)

\begin{tabular}{|c|c|c|c|c|c|c|}
\hline \multirow{3}{*}{ Level of education } & \multicolumn{6}{|c|}{ Risk of poverty } \\
\hline & \multicolumn{3}{|c|}{ European Union } & \multicolumn{3}{|c|}{ Poland } \\
\hline & 2010 & 2018 & Change in \% & 2010 & 2018 & Change in \% \\
\hline $\begin{array}{l}\text { Incomplete primary, primary } \\
\text { and lower secondary education }\end{array}$ & 15.9 & 19.3 & +21.4 & 30.9 & 23.3 & -24.6 \\
\hline Post-secondary education & 8.0 & 9.2 & +15.0 & 12.9 & 12.2 & -5.4 \\
\hline University education & 3.4 & 4.5 & +32.4 & 2.6 & 2.9 & +11.5 \\
\hline
\end{tabular}

Source: Eurostat. In-work at-risk-of-poverty rate by educational attainment level — EU-SILC survey [ilc_iw04].

A particularly significant increase in the number of the employed with university education at risk of poverty was observed in the following countries: Germany (increase by $30 \%$ ), the Netherlands (increase by $30 \%$ ), Malta (increase by $35.7 \%$ ), Spain (increase 
by $46.3 \%$ ), Bulgaria (increase by $50 \%$ ), Portugal (increase by $78.6 \%$ ), Italy (increase by 96.7\%), Luxembourg (increase by $129 \%$ ) and Hungary (increase by $233 \%$ ). In Poland, the increase in the number of employees with university education at risk of poverty grew by $11.5 \%$ in the period between 2010 and 2018. This phenomenon related to the pauperisation of individuals possessing university education is particularly dangerous. It may prove the deepening of the problem of lack of adjustment of courses offered by some colleges and universities to the needs of the rapidly changing economy. It may also be related to the increased supply of graduates of certain courses to the labour market, which in turn results in actual reduction of the level of their income.

As shown by results of empirical studies, crucial differences in the level of risk of poverty among the employed individuals are also connected with the stability of employment. In case of those employed on the basis of regular contracts of employment in the territory of the European Union the percentage of individuals at risk of poverty is more than twice lower than among those employed temporarily (Table 3). In 2018, the percentage of individuals at risk of poverty among employees possessing regular contracts of employment reached the level of 5.8\% whereas among those employed temporarily this value grew to $16.2 \%$. The situation in the Polish labour market is very similar - temporary employees are twice more frequently at risk of poverty in comparison with the permanently employed individuals. Surprisingly, although in the territory of the European Union we have observed an increase in the number of individuals at risk of poverty both among those employed permanently and temporarily. In Poland, the scale of occurrence of this phenomenon has been reduced.

Table 3. Stability of employment in relations to the risk of poverty of the working individuals in the territory of the EU and in Poland (comparison of the year 2010 to 2018 in \%)

\begin{tabular}{|l|c|c|c|c|c|c|}
\hline \multirow{2}{*}{ Stability of employment } & \multicolumn{6}{|c|}{ Risk of poverty } \\
\cline { 2 - 8 } & \multicolumn{3}{|c|}{ European Union } & \multicolumn{3}{c|}{ Poland } \\
\cline { 2 - 8 } & $\mathbf{2 0 1 0}$ & $\mathbf{2 0 1 8}$ & Change in \% & $\mathbf{2 0 1 0}$ & $\mathbf{2 0 1 8}$ & Change in \% \\
\hline $\begin{array}{l}\text { Permanently employees } \\
\text { (high level of stability) }\end{array}$ & 5.2 & 5.8 & +11.5 & 6.0 & 3.6 & -40.0 \\
\hline $\begin{array}{l}\text { Temporary employees } \\
\text { (low level of stability) }\end{array}$ & 13.3 & 16.2 & +21.8 & 11.8 & 9.7 & -17.8 \\
\hline
\end{tabular}

Important: it has been assumed that individuals employed permanently (most frequently on the basis of a regular contract of employment) are characterised by high level of stability in the labour market while for those employed temporarily the level of stability is low.

Source: Eurostat. In-work at-risk-of-poverty rate by type of contract — EU-SILC survey [ilc_iw05].

When comparing empirical data from 2010 and 2018 we may notice a considerable growth of individuals at risk of poverty among those employed temporarily namely from $13.3 \%$ in 2010 to $16.2 \%$ eight years later. Thus, the dynamics of threat of belonging to the 
category of the working poor is definitely higher - a fact proved by statistical data - if we take into consideration the level of employment stability.

Additionally, empirical data also prove that a crucial determinant influencing the level of poverty risk among the working individuals is whether they work full or part time. Those working part-time experience the phenomenon of poverty risk in connection with their job twice more frequently than individuals working full-time - this is true both for accumulative statistical data for the European Union and separately for Poland. However, there is one substantial difference: while in the period between 2010 and 2018 in the territory of the EU, an increase in the scale of this phenomenon was observed both among those employed full- and part-time in Poland the scale of this problem was reduced (Table 4).

Table 4. Full- and part-time employment in relation to the risk of poverty among working individuals in the EU territory and in Poland (comparison of the year 2010 to 2018 in \%)

\begin{tabular}{|c|c|c|c|c|c|c|}
\hline \multirow{3}{*}{ Working hours } & \multicolumn{6}{|c|}{ Risk of poverty } \\
\hline & \multicolumn{3}{|c|}{ European Union } & \multicolumn{3}{|c|}{ Poland } \\
\hline & 2010 & 2018 & Change in \% & 2010 & 2018 & Change in \% \\
\hline Working part-time & 12.5 & 15.2 & +21.6 & 20.6 & 19.0 & -7.8 \\
\hline Working full-time & 7.1 & 7.4 & +4.2 & 10.5 & 8.8 & -16.2 \\
\hline
\end{tabular}

Source: Eurostat. In-work at-risk-of-poverty rate by full-/part-time work — EU-SILC survey [ilc_ iw07].

One of the key factors affecting pauperisation of the professionally active individuals is the fact that they perform their work part time and in a wider perspective - in nonstandard forms of employment. It turns out that the flexibility of employment form is closely connected with the income marginalisation of an individual. Thus, we may propose a theory that the longer an individual functions on the margin of the labour market and lacks anchoring in the form of a regular work contract (e.g., is employed only for a definite period of time) the larger is the risk of poverty for such employees. Widespread exploitation of flexible forms of employment on one hand leads to wider range of possibilities of obtaining income but on the other it influences the obtained financial gratification negatively. As stated by Rafał Drozdowski, the term "flexible labour market" should nowadays be understood as definitely more liberal but not social conditions of employment - which only deepens and petrifies the inequalities between the representatives of the supply party (Drozdowski, 2002, pp. 106-109). Similarly, Elżbieta Kryńska strongly emphasises one of the basic negative features of flexible employment (e.g., civil law contracts, temporary jobs, job-sharing, part-time jobs and telework and others): from the perspective of an employee as these are usually badly paid positions (Kryńska, 2001, p. 113). 
The literature on the subject provides a series of arguments stressing the advantages of flexible forms of employment. For instance, Jules Gazon emphasises that "flexibility offered to companies by the possibility to resort to definite time and temporary employment may allow these employees to enter the labour market frequently constituting a transition stage before permanent employment" (2008, p. 68). Nevertheless - a fact emphasised also by the same author - wide possibilities of flexible employment of personnel may lead to the creation of a labour market "characterised by two speeds, in which the insiders frequently remain under the protection of the trade unions and benefit from high level of security and career opportunities while the outsiders are employed on the basis of insecure contracts" (Gazon, 2008, p. 68). Lack of stability in the labour market is also the subject of analyses by Polish researchers who emphasize the problem of social marginalization of temporary workers (Urbaniak, 2014, p. 16).

A dichotomous division into winners and losers is beginning to consolidate in the labour market. Winners are employed in the central sector which offers "relatively high salaries, favourable working conditions (...) stability of employment and protection of previously obtained employees' rights" (Kozek, 2014, p. 116). On the other hand, the peripheral market "offers badly paid positions, unstable, requiring more effort or intensity and offering small chances of promotion" (Kozek, 2014, p. 116).

Moreover, not only do individuals employed within the frames of flexible forms of employment obtain lower remuneration, but they also "are to a greater extent at risk of suffering the consequences of an economic crisis than the permanently employed personnel of companies" (Muster, 2012, p. 41). Such individuals - in case of an economic downturn - will lose their jobs first due to low stability of their employment and low level of trade unions protection. The percentage of employees at risk of poverty is also clearly corelated with their seniority. For instance, among individuals with seniority shorter than one year, the percentage of those at risk of pauperisation in the EU labour market reached the level of $16.8 \%$ in 2018, while for employees with seniority longer that one year the same value was nearly twice lower and reached the level of $8.8 \%$. For the employed in Polish labour market with seniority below and above one year, values of these indicators were similar with one difference - while in the EU states an increase of poverty risk indictors was observed, in Poland a reduction of the scale of this problem was recorded (Table 5).

Table 5. Work seniority versus risk of poverty among the employed citizens of the EU and in Poland (comparison of the year 2010 to 2018 in \%)

\begin{tabular}{|l|r|r|c|c|c|c|}
\hline \multirow{2}{*}{ Work seniority } & \multicolumn{6}{|c|}{ Risk of poverty } \\
\cline { 2 - 7 } & \multicolumn{3}{|c|}{ European Union } & \multicolumn{3}{c|}{ Poland } \\
\cline { 2 - 7 } & $\mathbf{2 0 1 0}$ & $\mathbf{2 0 1 8}$ & Change in \% & $\mathbf{2 0 1 0}$ & $\mathbf{2 0 1 8}$ & Change in \% \\
\hline Less than a year & 14.8 & 16.8 & +13.5 & 17.4 & 15.8 & -9.2 \\
\hline At least a year & 7.9 & 8.8 & +11.4 & 9.5 & 9.3 & -2.1 \\
\hline
\end{tabular}

Source: Eurostat. In-work at-risk-of-poverty rate by months worked — EU-SILC survey [ilc_iw06]. ${ }^{4}$

4 On EU-SILC: see: EU-SILC, 2003. 
The criterion of work seniority is naturally closely connected with the age of the employed. Thus, we can conclude with a sound degree of probability that individuals with a short period of seniority are mostly young people entering the space of the labour market and commencing their professional careers.

Another factor with considerable influence on the problem of pauperisation of the employed is connected with the size of the household. Poverty risk indicators for employed individuals differ depending on whether these individuals belong to households with or without children (Table 6).

Table 6. Type of household versus poverty risk among the employed in the EU and in Poland (comparison of the year 2010 to 2018 in \%)

\begin{tabular}{|c|c|c|c|c|c|c|}
\hline \multirow{3}{*}{ Type of household } & \multicolumn{6}{|c|}{ Risk of poverty } \\
\hline & \multicolumn{3}{|c|}{ European Union } & \multicolumn{3}{|c|}{ Poland } \\
\hline & 2010 & 2018 & Change in \% & 2010 & 2018 & Change in \% \\
\hline Household without children & 6.2 & 7.8 & +25.8 & 8.2 & 8.3 & +1.2 \\
\hline Household with children & 10.5 & 10.8 & +2.9 & 13.9 & 10.3 & -25.9 \\
\hline
\end{tabular}

Source: Eurostat. In-work at-risk-of-poverty rate by household type — EU-SILC survey [ilc_iw02].

An analysis of the empirical data suggests that in the European Union territory, households without children in which at least one individual obtains income from employment are at smaller risk of pauperisation in comparison with households with children. In case of childless households, the percentage of those at risk of poverty in the EU labour market reached the level of $7.8 \%$, whereas in case of households with children this percentage grows to $10.8 \%$. For Poland, these indicators amounted to, respectively: $8.3 \%$ and $10.3 \%$.

At the same time, it should be taken into account that when determining the problem of working people pauperisation, the total disposable income of all household members, including social transfers, is considered. Reducing the problem of the risk of poverty in Poland among families with children in recent years can be explained, among others, by the large social programs, incl. $500+$, whose beneficiaries are families with children.

The final analysed variable related to the issue of risk of poverty among the employed is work intensity of the household - Table 7. As stated in the literature on the subject the intensity of work is measured as "the relation of the number of months which all members of the household worked in a given year to the total amount of months during which they could work. In this interpretation, both part-time work and working for only some period of the year will reduce work intensity. Work intensity is evaluated within the scale from 0 to 1 . The value 0 signifies that no individual of working age belonging to the given household worked in the analysed period while value 1 signifies that all individuals worked full time throughout the whole analysed period" (Siergiejczuk, 2018, p. 20). In compliance with the methodology assumptions of EU-SILC, five categories 
of work intensity of a household have been used: very high (0.85-1.0), high (0.55-0.85), medium (0.45-0.55), low (0.2-0.45) and very low (0.0-0.2).

Table 7. Level of work intensity of the household versus risk poverty of the employed in the EU and in Poland (comparison of the year 2010 to 2018 in \%)

\begin{tabular}{|l|r|r|r|r|r|r|}
\hline \multirow{2}{*}{$\begin{array}{c}\text { Level of work intensity } \\
\text { of the household }\end{array}$} & \multicolumn{5}{|c|}{ European Union } & \multicolumn{3}{c|}{ Poland } \\
\cline { 2 - 7 } & $\mathbf{2 0 1 0}$ & $\mathbf{2 0 1 8}$ & Change in \% & $\mathbf{2 0 1 0}$ & $\mathbf{2 0 1 8}$ & Change in \% \\
\hline $0.85-1$ (very high) & 4.4 & 5.1 & +15.9 & 7.1 & 6.4 & -9.9 \\
\hline $0.55-0.85$ (high) & 8.7 & 10.2 & +17.2 & 13.7 & 10.3 & -24.8 \\
\hline $0.45-0.55$ (medium) & 18.7 & 23.0 & +23.0 & 20.2 & 18.3 & -9.4 \\
\hline $0.2-0.45$ (low) & 33.5 & 37.0 & +10.4 & 38.7 & 36.5 & -5.7 \\
\hline $0.0-0.2$ (very low) & no data & no data & no data & no data & no data & no data \\
\hline
\end{tabular}

Source: Eurostat. In-work at-risk-of-poverty rate by work intensity of the household (data for individuals aged 18-59) - EU-SILC survey [ilc_iw03].

The conducted analysis of the gathered empirical material clearly proves the existence of dependency between the level of work intensity of the household and potential risk of poverty. In households characterised by very high work intensity the factor of poverty risk in 2018 for all the EU states equalled 5.1\%. In terms of comparison, in Poland, the same factor reached the level of $6.4 \%$. Subsequently, the value of the risk factor clearly rises with decreasing work intensity, both when observing the average for the EU states and for Poland.

\section{Additional research proposal}

The Eurostat research allows for the performance of international comparisons. However - a fact that needs emphasising - these data are typically quantitative in their nature and refer to the scale of the phenomenon, also presenting its statistical dimension. They inform us "how many" individuals belong to the category of the working poor and define their basic social and demographic characteristics. Yet, these analyses do not take into consideration the issues related to the problem of standard of living or working conditions of these individuals. Obtaining answer to the question regarding the motives for providing work frequently in several places to be able to "make ends meet" is definitely worth the effort. Which factors determine professional activity of these employed? In-depth research and analysis of the induced materials both of quantitative and qualitative nature would definitely enhance obtaining answers to the questions structured in this manner. 
The proposal of research into the issue of the working poor - in terms of methodology issues - could be connected with the concept of methodological triangulation. This signifies application of various methods of gathering empirical material, thus guaranteeing a comprehensive nature of the gathered empirical metrical with smaller risk of mistakes. On one hand, performing qualitative research could be recommended - these would include, for instance, representative studies allowing for the performance of an analysis at the national level. In this case, standardised survey or interview questionnaires might be used. The module of quantitative nature could be extended with qualitative analyses. These could include more in-depth interviews with representatives of the professions which are particularly threatened by pauperisation. Apart from the resulting materials, one could also recommend the analysis of already existing materials (e.g., statistical data, previous reports and others).

In order to capture the dynamics of occurring changes in the scope of the phenomenon of working poor, periodicity of these studies could also be proposed. The repetitiveness of analyses would definitely enhance capturing the influence of periodicity of changes in economy onto the scale of intensity of this phenomenon. A new dimension of poverty afflicting professionally active individuals would be the problem of pauperisation resulting from the effects of the global COVID-19 pandemics, contributing not only to the loss of jobs by part of employees but also to obtaining lower incomes by representatives of numerous professions. As it has been stressed by Julien Damon while health victims of the pandemics are predominantly the elderly, the economic victims of this situation, unprecedented in modern history, include mostly younger individuals ${ }^{5}$. Representatives of the younger generations are particularly affected by the problem of precarity or insecurity in the labour market. This is related to the fact that these individuals - if they are professionally active - frequently work not on the basis of regular contract of employment, but of other atypical forms of employment.

\section{Summary and conclusions}

A disturbing phenomenon in contemporary European labour market is the increase of the percentage of professionally active individuals facing the risk of income marginalisation and in consequence, poverty. In recent years, the largest growth of this phenomenon was observed in Bulgaria, Spain, Luxembourg, Germany, Hungary and Italy. Thus, we may conclude that the increase in the scale of this phenomenon concerns countries strongly diversified in terms of their economic growth indicators. However, in Poland, in the period between 2010 and 2018, a decline in the occurrence of this phenomenon was registered. During the analysis of the issue of pauperisation of the employed in the contemporary labour market, it is difficult to pinpoint one key factor determining belonging to the category of working individuals at risk of poverty. Lack of homogeneity

5 See: (https://wydarzenia.interia.pl/raporty/raport-koronawirus-chiny/aktualnosci/news-pandemia-koronawirusa-a-ubostwo-prof-julien-damon-ofiarami-e,nId,4788024). 
among individuals classified within this category is often emphasised in the literature on the subject: "Working poor do not constitute a homogenous group and particular individuals differ from one another considerably. Their common feature, however, is the instrumental nature of performed work and its precarity" (Kalinowski \& Luczka, 2015, p. 113). Nevertheless, statistical analyses conducted on the basis of EU-SILC survey allow for pinpointing several variables clearly increasing the probability of occurrence of this problem among professionally active individuals - both in the space of the European labour market and in direct reference to Poland. These factors are frequently connected with, for instance, a low level of formal education of an employee may be related to longterm performance of work on the basis of flexible forms of employment, which, in turn will imply the issue of long-term income marginalisation Moreover, individuals employed within flexible forms of employment are at greater risk of losing their jobs or reduction of obtained income in case of an economic crisis.

Other factors clearly connected with the problem of pauperisation of professionally active individuals are correlated with their age and seniority - the problem of poverty touches mostly younger individuals with short period of professional experience. Moreover, as shown by the performed analysis, this problem affects individuals living in households with children and also, more frequently with low indicators of work intensity (compare also: Muster, 2016). M. Leszczyńska adds that income poverty affects individuals residing in the countryside and small towns to a greater extent (2007, p. 103). Naturally, the economic standing also influences the level of incomes of households. In the period of crisis companies apply the policy of cost reduction resulting not only in growing unemployment rate but also real decline of employees' remuneration (compare Nawrot, 2009, p. 83; Adamowicz et al., 2017, p. 16).

Progressing deindustrialisation, development of sector of services and particularly the increase in the number of workplaces in the sector of badly paid services (e.g., fast food restaurants, trade, security services, cleaning services etc.) all constitute factors of crucial importance enhancing pauperisation of those who perform this type of badly paid jobs. Currently, the problem of pauperisation of the employed concerns mostly these individuals who are professionally connected with the sector of services and particularly the type of services for which high qualifications are not required. A further increase in the percentage of individuals classified as working poor may be predicted - in the future also in the Polish labour market due to "increasing differentiation in the scope of salaries and also low level of qualifications of a considerable group of employees" (Goleński, 2015, p. 20). As observed by E. Kuźmicz: "Taking into consideration the probable growth of the services sector in Polish economy and the fact that it is not the sector with high salaries (at least certain areas of this sector which usually employ individuals with low qualifications) it is highly likely that in the future the percentage of working poor shall be growing" (Kuźmicz, 2011, pp. 47-48).

Simultaneously, it needs to be strongly emphasised that the problem of pauperisation also affects - although to a definitely smaller extent - well-educated employees belonging to the category of white-collar workers. In the state-of-the-art, even a special 
term "officeriate" appears describing well educated employees who perform office and administrative work for low salaries frequently no higher than the level of the national minimum salary (compare: Kapiszewski, 2013; Szaban, 2013). More attention should be devoted to the problem of pauperisation of the employed, especially taking into consideration the deficit of studies in this area. A series of question arises - particularly in the context of changes occurring in the labour market - questions, answers to which, could be provided by properly conducted research. The key question concerns the motives of performing work by individuals obtaining low financial gratification - sometimes at the level similar to potential social transfers in case of lack of professional activity. Further questions are related to the strategy of dealing with the difficult material situation.

Currently, we are observing an advancing division in the labour market - if we want to apply the sport terminology here - the division into "winners" and "losers". Not only does this division result not only from considerable differences in obtained incomes but it also stems from different opportunities for professional development or achieving relevant job security. Certainly, working individuals with high incomes and stable situation in the labour market might be classified as "winners" when discussing the employed. This group of employees is provided with opportunities of developing their qualifications, they are employed by companies located in the so-called primary labour market. On the other hand, not only do "losers" in the labour market have an unstable workplace, but they also obtain low financial gratification, have limited opportunities of professional development and they are employed by companies belonging to the secondary labour market. The problem of income marginalisation is very often accompanied by lack of trade union protection. A longer period of functioning of an individual in the outskirts of the labour market connected with performance of badly paid jobs may contribute to the intensification of income marginalisation of such an individual.

The consequences of pauperisation of professionally active individuals should be analysed at several layers. Low financial gratification for performed work which frequently places such individual and their family below the poverty threshold evokes frustration. This shall in turn lead to social discontentment, increase of support for populist groups, xenophobic attitudes, intolerance and aggression directed at migrants and representatives of minorities. Moreover, in the economic dimension we may notice the problem of young generation struggling to become independent of their parents due to low incomes and insecure jobs and consequently, problems with purchasing their own flat (compare: Budnik, 2019, pp. 160-161). Lack of effects of the performed work in the form of improvement of the standard of living may also lead to deactivation, resignation from work and further consolidation of passive attitudes focused on benefiting from social transfers. 


\section{References}

Adamowicz, M., Miklaszewska, W., Adamowicz, T. (2017). Światowy kryzys finansowy i działania naprawcze wobec gospodarki polskiej, Polityki Europejskie, Finanse i Marketing, 17(66), 5-24.

Arora, V. S., Karanikolos, M., Clair, A., Reeves, A., Stuckler, D., McKee, M. (2015). Data Resource Profile: The European Union Statistics on Income and Living Conditions (EU-SILC), International Journal of Epidemiology, 44(2), 451-461.

Budnik, M. (2019). Socjologia pracy w zarysie. Wydawnictwo Difin SA.

Collins Cobuild English Language Dictionary (1990). Collins.

Crettaz, E. (2013). A state-of-the-art review of working poverty in advanced economies: theoretical models, measurement issues and risk groups, Journal of European Social Policy, 23(4), 347-362.

Cymbranowicz, K. (2017). Analiza i ocena zjawiska working poor w Polsce na tle Unii Europejskiej. In M. Romanowska (ed.), Wspótczesne problemy ekonomii - między teoria a praktyka gospodarcza w aspekcie różnorodności. (170-178). Polskie Towarzystwo Ekonomiczne o/Częstochowa.

Czarzasty, J. (2020). Od stoczniowców do prekariuszy. Trzydzieści lat badań nad gospodarką dobrze urządzoną w SGPiS/SGH. In A. Mrozowicki, J. Czarzasty (ed.), Oswajanie niepewności. Studia społeczno-ekonomiczne nad mtodymi pracownikami sprekaryzowanymi. (73-99). Wydawnictwo Naukowe Scholar.

Domański, H. (2007). Struktura społeczna. Wydawnictwo Naukowe Scholar.

Domański, H. (2012). Metodologia badań nad stratyfikacja społeczna. Wydawnictwo Naukowe Scholar.

Drozdowski, R. (2002). Rynek pracy w Polsce. Recepcja, oczekiwania, strategie dostosowawcze. Wydawnictwo Naukowe UAM.

Ehrenreich, B. (2006). Za grosze. Pracować i (nie) przeżyć. Wydawnictwo W.A.B.

EU-SILC, (2003). Regulation of the European Parliament No. 1177/2003, 16 July 2003 (with the modifications contained in Regulation 1553/2005) concerning Community Statistics on Income and Living Conditions (EU-SILC).

Frieske, K. (2008). Społeczna marginalność jako koszt systemowy. In M. Jarosz (ed.), Wykluczeni. Wymiar społeczny, materialny i etniczny. (19-41). ISP PAN.

Frysztacki, K. (2009). Socjologia problemów społecznych. Wydawnictwo Naukowe Scholar.

Gardawski, J. (ed.) (2009). Polacy pracujacy a kryzys fordyzmu. Wydawnictwo Naukowe Scholar.

Gazon, J. (2008). Ani bezrobocie ani opieka spoteczna. Od wyboru etycznego do ekonomicznej realizacji. PWN.

Góra, M. (2016). Prekaryzacja rynku pracy. In A. Górny, P. Kaczmarczyk, M. Lesińska (ed.), Transformacje. Przewodnik po zmianach spoteczno-ekonomicznych w Polsce. Wydawnictwo Naukowe Scholar.

Goleński, W. (2015). Pracujący biedni w Polsce — definicja, główne przyczyny, zjawiska powiązane. Polityka Spoteczna, 2, 16-21. 
Golinowska, S. (2018). O polskiej biedzie w latach 1990-2015. Definicje, miary $i$ wyniki. Wydawnictwo Naukowe Scholar.

Greulich, A. \& Dasré, A. (2017). The quality of periodic fertility measures in EUSILC. Demographic Research, 36(17), 525-556.

Grotowska-Leder, J. (2018). Podejście dynamiczne w badaniach ludzi młodych z perspektywy rynku pracy — aspekty poznawcze i aplikacyjne, Rocznik Lubuski, 44(1), 33-53. GUS. (2014). Dochody i warunki życia ludności Polski (raport z badania EU-SILC 2013). Warszawa.

Hardy, J. (2010). Nowy polski kapitalizm. Instytut Wydawniczy Książka i Prasa.

Kalinowski, S. (2015). Ubóstwo ludności wiejskiej o niepewnych dochodach, Roczniki Naukowe Ekonomii Rolnictwa i Rozwoju Obszarów Wiejskich, 102(1), 85-96.

Kalinowski, S., Łuczka, W. (2015). Biedni pracujący w Unii Europejskiej - wybrane problemy, Roczniki Naukowe Stowarzyszenia Ekonomistów Rolnictwa i Agrobiznesu, 17(5), 112-117.

Kapiszewski, J. (2013). Officeriat. W Polsce narodziła się nowa, niezamożna klasa robotnicza, Gazeta Prawna, 08.05.2013.

Kiersztyn, A. (2007a). Underemployment — nowe zjawisko, czy nowy termin? Polityka Spoteczna, 10, 17-26.

Kiersztyn, A. (2007b). Who Works for Less? Contingent Work and Underemployment. In K. M. Słomczyński, S. T. Marquart-Pyatt (ed.), Continuity and Change in Social Life: Structural and Psychological Adjustment in Poland. (153-180). IFiS.

Kiersztyn, A. (2014). Employment Instability. A Dynamic Perspective, International Journal of Sociology, 42(1), 6-30.

Kiersztyn, A. (2018). Labour market precarity and political alienation. Przeglad Socjologiczny, 67, 35-61.

Kiersztyn, A. (2020). Niepewność zatrudnienia młodych dorosłych: analiza sekwencji karier zawodowych, Biuro Analiz Sejmowych, 73-90.

Kiersztyn, A., Słomczyński, K. M., Życzyńska-Ciołek, D. (ed.) (2017). Rozwarstwienie spoteczne: zasoby, szanse i bariery. Wyd. IFiS PAN.

Kozek, W., Kubisa, J., Ostrowski, P. (2005). Bliżej junk job niż working poor. Nisko kwalifikowana nisko płatna praca w usługach w Polsce. Polityka Społeczna, 10, 1-8.

Kozek, W. (2014). Rynek pracy. Perspektywa instytucjonalna. Wydawnictwo Uniwersytetu Warszawskiego.

Krasowska, A. (2020). Biograficzne doświadczenie pracy młodych pracowników sprekaryzowanych. In A. Mrozowicki, J. Czarzasty (ed.), Oswajanie niepewności. Studia spoteczno-ekonomiczne nad młodymi pracownikami sprekaryzowanymi. (117-134). Wydawnictwo Naukowe Scholar.

Kryńska, E. (2001). Dylematy polskiego rynku pracy. Instytut Pracy i Spraw Socjalnych.

Kryńska, E. (2017). Ekonomiczny kontekst problemu społecznego — przypadek prekariatu, Problemy Polityki Spotecznej. Studia i Dyskusje, 1, 13-26.

Kubisa, J. (2014). Bunt biatych czepków. Analiza dziatalności związkowej pielęgniarek i położnych. Scholar. 
Kuźmicz, E., Stasiowski, J. (2008). Pracujący biedni. Komunikat z badań. Centrum Badania Opinii Społecznej.

Kuźmicz, E. (2011). Bieda pracujących, czyli working poor po polsku. In M. Popow, P. Kowzan et al. (ed.), Oblicza biedy we wspótczesnej Polsce. (37-62). Wydawnictwo Doktoranckie Koło Naukowe „Na Styku” Instytut Pedagogiki Uniwersytetu Gdańskiego.

Leszczyńska, M. (2007). Ubóstwo dochodowe w Polsce - tendencje i uwarunkowania. In J. Klebaniuk (ed.), Oblicza nierówności społecznych. Studia interdyscyplinarne. (93-109). Wydawnictwo Eneteia.

Mrozowicki, A. (2020). Badania biograficzne nad młodymi pracownikami sprekaryzowanymi: kontekst metodologiczny. In A. Mrozowicki, J. Czarzasty (ed.), Oswajanie niepewności. Studia spoteczno-ekonomiczne nad młodymi pracownikami sprekaryzowanymi. Wydawnictwo Naukowe Scholar.

Muster, R. (2011). Pracujący biedni na współczesnym rynku pracy — problemy definicyjne i próba analizy zjawiska, Humanizacja Pracy, no 5, pp. 63-79.

Muster, R. (2012). Pracujący biedni na rynku pracy. Procesy uelastyczniania zatrudnienia a zjawisko pauperyzacji pracowników, Studia Socjologiczne, 3, 29-47.

Muster, R. (2016). Pauperisation of Employees in the Domestic Labour Market, Warsaw Forum of Economic Sociology, 7, 1(13), 43-53.

Nawrot, W. (2009). Globalny kryzys finansowy XXI wieku. Przyczyny, przebieg, skutki, prognozy. Wydawnictwo CeDeWu.

Newman, K. S. (1999). No Shame in My Game. The working poor in the Inner City. Russell Sage Foundation.

Newman, K. S. (2006). Chutes and Ladders. Navigating the Low-Wage Labour Market, Russell Sage Foundation and Harvard University Press.

Newman, K. S. \& Tan Chen V. (2007). The Missing Class. Portraits of the Near Poor in America. Beacon Press.

Nowakowska, K. (2014). Pracują ale pozostają ubodzy. Kim są polscy pracujący ubodzy? Gazeta Prawna, 30.09.2014.

Nowakowska, K. (2018). Biedni robią w biedzie. Pracownicy socjalni mają gorzej niż ich podopieczni. Gazeta Prawna, 12.10.2018.

Pena-Casas, R. \& Latta, M. (2004). Working Poor in the European Union. European Foundation for the Improvement of Living and Working Conditions. Luxemburg: Office for Official Publications of the European Communities.

Polak, E. (2011). Problem ubóstwa a polityka kształtowania dochodów w Polsce na tle krajów Unii Europejskiej - wybrane aspekty, Nierówności Społeczne a Wzrost Gospodarczy, 18, 98-111.

Polkowska, D. (2016). Feminizacja prekariatu. Polska na tle innych krajów Europy. Annales: etyka w życiu gospodarczym, 19(2), 31-49.

Raczkowska, M. (2015a). Nierówności dochodowe w Polsce, Studia i Prace Wydziału Nauk Ekonomicznych i Zarządzania, 41(2), 345-356. 
Raczkowska, M. (2015b). Nierówności dochodowe w Polsce w relacji miasto-wieś. Zeszyty Naukowe Szkoty Gtównej Gospodarstwa Wiejskiego, Ekonomika i Organizacja Gospodarki Żywnościowej, 112, 111-124.

Rąb, K. \& Rąb, Ł. (2015). Precariat and precarious work as negative factors affectinging sustainable development, Zeszyty Naukowe Politechniki Ślaskiej, 81, 167-174.

Riffkin, J. (2003). Koniec pracy. Schytek sity roboczej na świecie i początek ery postrynkowej. Wydawnictwo Dolnośląskie.

Shipler, D. K. (2005). The Working Poor: Invisible in America. Vintage Books.

Siergiejczuk, M. (2018). Ubóstwo $i$ wykluczenie społeczne $w$ Polsce $i$ innych krajach Unii Europejskiej w latach 2008-2016. Departament Analiz Ekonomicznych i Prognoz Ministerstwo Rodziny, Pracy i Polityki Społecznej.

Stanaszek, A. (2004). Bieda (z)pracy, czyli o biednych pracujących we współczesnym świecie. Kultura i Spoteczeństwo, 2, 143-169.

Standing, G. (2014). Prekariat. Nowa niebezpieczna klasa. Wydawnictwo PWN.

Standing, G. (2015). Karta prekariatu. Wydawnictwo PWN.

Stepaniuk, J. (2018). Współcześni polscy nauczyciele jako biedni pracujący, Podstawy Edukacji, 11, 117-129.

Suchodolska, M. (2015). Pracujący biedni: harują, ale zarabiają grosze. Jest ich w Polsce coraz więcej, Gazeta Prawna, 12.09.2015.

Swartz, T. S., Weigert, K. M. (1996). America's Working Poor. University of Notre Dame Press.

Szaban, J. M. (2013). Rynek pracy w Polsce i w Unii Europejskiej. Wydawnictwo Difin.

Szamrej-Baran, I. (2014). Ubodzy pracujący w Polsce na tle Unii Europejskiej. Studia i Prace Wydziału Nauk Ekonomicznych i Zarzadzania, 35, 291-304. Wydawnictwo Naukowe Uniwersytetu Szczecińskiego.

Szczepański, M. S., Maciejewski, G., Gawron, G. (2006). Społeczne koszty polskiej transformacji. Wykluczenie społeczne, czyli lądowanie na marginesach? In E. Jurczyńska-McCluskey, M. S. Szczepański, Z. Zagała (ed.), Równi i równiejsi. Zwycięzcy i przegrani. Dynamika zróżnicowań spotecznych w Polsce na przełomie XX $i$ XXI wieku. (15-26). Wydawnictwo WSZiNS Tychy i ATH Bielsko-Biała.

Therborn, G. (2015). Nierówność, która zabija. Jak globalny wzrost nierówności niszczy życie milionów i jak z tym walczyć. Wydawnictwo PWN.

Urbaniak, B. (2014). Praca okresowa przejawem rosnącej niepewności na rynku pracy. In B. Urbaniak, P. Oleksiak, Praca tymczasowa. Droga do kariery, czy ślepy zaułek? (15-32). Wydawnictwo Uniwersytetu Łódzkiego.

Wójcik-Żołądek, M. (2013). Bieda pracujących. Zjawisko working poor w Polsce, Studia Biura Analiz Sejmowych, 4, 159-178.

Zabielska, J. M. (2007). Ubóstwo a procesy marginalizacji społecznej. Wydawnictwo KUL. Zelek, A. (2018). Kryzysy były, są i będą - o przesłankach kolejnego kryzysu gospodarczego, Zeszyty Naukowe ZPSB Firma i Rynek, 2(54), 5-19. 
Online sources

www.ec.europa.eu/eurostat

http://appsso.eurostat.ec.europa.eu/nui/submitViewTableAction.do

https://stat.gov.pl

http://ha.art.pl/prezentacje/39-edufactory/1655-jan-sowa--co-to-jest-prekariat.html

https://wydarzenia.interia.pl/raporty/raport-koronawirus-chiny/aktualnosci/news-pande-

mia-koronawirusa-a-ubostwo-prof-julien-damon-ofiarami-e,nId,4788024

https://www.bls.gov/opub/reports/working-poor/2018/home.htm

https://poverty.ucdavis.edu/faq/who-are-working-poor-america 